\title{
PERSISTENT WOMEN POETS OF IRAN: THEIR GROWTH THROUGH HARDSHIPS
}

\author{
Md. Mumit Al Rashid ${ }^{1}$ \\ Tanjina Binte Nur ${ }^{2}$
}

\begin{abstract}
Poetry has always been the noteworthy face of Iran's cultural identity. Persian poets and their poems have reconstructed and revolutionized both the Eastern and Western literary world. Sadly, in a male-dominated Iranian society, female literary talents had been sidelined throughout centuries. Still, there were some iconic female poets who have blended their poetical talents with very powerful mental strength to cut off all the societal limitations, taboos and prohibitions and had left their marks on Persian literature's history forever. But to attain that, they had to come across a long way. As the title indicates, the subject of this article is about the growth of some of those persistent women poets of Iran, with an emphasis on the hardships they have faced and how they overcame through those phases. In short, this article analyses the problems of women poets in the context of the socio-political environment of Iran and discuss the efforts the women poets have to made to break those barriers. The Central Library of Dhaka University, Departmental Library of Persian Language and Literature, DU and original Persian manuscripts from the authors personal collections are used as the primary resources for this article as well as online helpful websites.
\end{abstract}

Keywords: Persian Women poets, Parvin E'tesami, Forough Farrokhzad, Simin Behbahani, Granaz Mousavi.

\section{Introduction}

Persian being the state language of Iran, country's literature is known as 'Persian Literature' worldwide. There is no doubt on that the credit of Modern Persian

\footnotetext{
1 Md. Mumit Al Rashid, PhD is Associate Professor, Department of Persian Language and Literature, University of Dhaka. Email: mumitarashid@du.ac.bd

2 Tanjina Binte Nur, M. Phil Researcher, Department of Persian Language and Literature, University of Dhaka. E-mail: tanjinabnur88@gmail.com.
}

Social Science Review [The Dhaka University Studies, Part-D], Vol. 38, No. 1, June 2021 DOI: https://doi.org/10.3329/ssr.v38i1.56526 
literature goes to both men and women writers of the country. But the sad truth is that the Iranian women came in limelight of the Persian literature after a very long time. According to the history, till the end of nineteenth century, very few women litterateurs got chance to show their talent in the field of literature. In fact, from the fourth century to the beginning of the famous constitutional era in Iran, poetry of women writers was barely known (Brown, 1969, p.349). For a long period of time, women writing talents were mostly channelled away from public forms of written self-expression (Milani, 1992, p.177-178). Presence of women were there in classical Persian poetry, but not as their writer, but as the subject of the writing. Those poems were composed from the perspective of man's love towards the ladies. In other words, Political, social, and cultural infrastructures had, in the past, been subjected to the role of women behind the scenes; but women have contributed significantly to the transformation and collapse of each of them and the great contributions they have made to Persian poetry and culture is worth mentioning (Hamideh, 2007, p.48). With so many barriers for them in Iran's historical culture, Poetry was the only art form left for women writers to express their feelings. Their prime focus on those poetical attempts were to change the direction from being the beloved to their insights and thoughts. Poet like Parvin E'tesami showed Iranian women the internal face of their own needs and desires and forced them to look back to their roots. Then female poets such as Forough Farrokhzad, Tahereh Saffarzadeh, Simin Behbahani, Granaz Mousavi- bravely pointed to the female insights and has risen rebelliously against the hypocrisy of masculine domination in a traditional society.

The present study proposes a fresh evaluation of some of the notable Iranian women poets and their poetical journey- from the beginning of women's poetry in Iran to their position in modern Persian poetry, through the hardships.

\section{Birth of Women's Poetry in Iran}

Persian literature has presented the Persian language and culture to the world for more than a thousand years. The legacy is enriched by traditional forms, from epic to lyric to fables. But it is Persian poetry, that has always been the prevailing genre (Mirabedini, 2005). In classical and pre-constitutional era, women have little face in poetry, and this inadequacy has reflected the patriarchal culture of society. It was impossible for a woman, who did not even have a place in 
classical poetry, to think of becoming a poet. And if she did, she would have been killed by her own family. There were not many poets before the Constitutional Movement (popularly known as Mashrute) and a very few of those poets were heard. Four such poets are: Rabeie Qaddari or Rabia Bint Ka'ab- the fourthcentury poet who fell in love with her brother's slave and was killed by her brother (Rypka, 1968); Mahasti Ganjavi- poet of philosophical quatrains of late fifth and early sixth century; Jahan Malek Khatoon- poet of the eighth century; and Mehri Heravi-poet of the ninth century. After them, a long silence was there, and no male poets took women poets seriously. Even the literal biographies were written without their mention at all (Chopra, 2010). Among the female poets of the Qajar era, names of Rigash Begum, Alam al-Taj Ghaem Maghami, Zandokht Shirazi can be mentioned whose name even has not been heard by many people. In medieval times, Persian-speaking women who themselves belonged to the privileged society class got the opportunity of education and had their means to write and recite poetry. Fakhr Adel Khalatbary, Robab Esfahani, Shams Kasmaee, Mehrtaj Rakhshan, Jale Ghaem Maghami, Nimtaj Salmasi are some of the notable names of this period who tried to bring a social rebellion for Iranian women writers.

The veins of modernization by the women protesting for the status quo sparked after the constitutional movement and greatly contributed to the presence of women in various fields, especially in poetry (Moghaddam, 2019). These small shakes for women came out of a society that had always kept big and smart women behind the bars; women who despite their great power were sacrificed for the survival of the masculine power in the socio-political spheres; women who had great potential for being teachers, doctors, lawyers, and ministers, but again the culture of society did not allow for much of an emergence, and the general belief in women was the same as that of the past. But in any case, women were able to get out of the inner corner, and in the year 1973, there were more publications for women. From the second half of the nineteenth century, Iran came in direct contact with the Western world, particularly Europe (Sattari, 2009). Through the modern educational institution named Dar-ul-Funun, established by Amir Kabir in 1852, many students got chance to pursue foreign education in Iran as well as in Europe. Those students who had been to Europe, returned with western culture, literature, and the modern technology. They understood the very need of women empowerment. During the Constitutional Revolution, Iranian educated women took active part in it, and they voiced their 
needs to be heard and to be seen. For them, this revolution came as an opportunity to liberate themselves as well. It was at this juncture of Iranian history that female literature, specifically poetry, became an important vehicle for women's struggle for freedom (Shafi'i Kadkani, 2013).

\section{Persistent Women Poets of Iran: Their Growth Through Hardships}

Women writers of Iran began to appear in the 1930's, but various socio-political limitations blocked them from flourishing. After the first decade of the movement, the ratio was 5:1 female writer in contrast of male litterers (Mirabedini, 2005). But revolutions brought changes to the women's insight, and they decided to turn into change-makers. In the post-revolutionary period, female poets of Iran crossed over the socio-cultural barriers with only one strategy: to be seen and heard more, and to resist and create a new self identity.

Modern Persian literature, with all its modernity and literal necessities, is undoubtedly by and for the women. Poems written by them has earned a momentous and great place in Modern Iran as the women litterateurs are more realistic to represent the women issues in front of the society (Kianush, 1996). But as discussed, it only became possible for the strong and persistent women writers of the times, who fearlessly stepped forward to turn the change to the reality and became the pioneer of female poetry in Iran by overcoming all the hardships that came their way. The first notable female poet of Persian literature can be named is Fatimah Baraghani- a nineteenth century poet, a forbidden legend. Thereafter, Parvin E'tesami, Forough Farrokhkzad, Simin Behbahani, Granaz Mousavi- are the names whose contribution to Persian poetry is worth mentioning for their outstanding poetical skill.

\section{Fatimah Baraghani (1814-1852): A fearless feminist poet}

Fatimah Baraghani, famously known as 'Tahirih' (the Pure one) in the Iranian Literary History. She is also known by other names, like Zarrin Taj Kazvini and Qurratul 'Ayn (Solace of the Eyes). Except for Fatimah Baraghani, all these names are her honorary titles (Hatcher \& Hemmat, 2008, p.1-2). She was born in Qazvin, Iran in 1814. She was the eldest daughter of Muhammad Saleh Baraghani (Effendi, 1944, p.72). She can be regarded as the first fearless feminist poet of Iran, though none of her poems were published. Her intellectual struggles and tragic execution have made her an icon in the struggle for women's 
independence and liberty (Ma'ani, 2008). Her father educated her in Persian literature and poetry privately. Her interest to law and jurisdiction attracted her to the Babi religious movements. She was a well-educated and very talented girl of her era. In the early 1840's, she became familiar with the Shaykhi Mazhab. Syed Kazim Rashti, who was a great scholar of this Mazhab, crowned her with the title of "Qurratul 'Ayn", after seeing her outstanding and extra-ordinary talent (Abedi, 1380, p.15).

Tahirih is best known for unveiling herself in front of the crowd full of men during the Conference of Badasht. After this event she was kept under housearrest in Tehran (Maneck, 1994). She was executed secretly for her Babi faith and breaking social rules by unveiling herself in mid-1852 (Root, 2000). Babi literature mentioned her as the first woman suffrage "Martyr" and titled her as "Tahirih-The Pure One", to show their support and love to her (Smith, 2000, p.332). Poems attributed to Tahirih are not found in large amount. It consists about sixty short and medium length poems. As she had to battle with her family throughout her life, most of her poems were destroyed-during her life and after her death (Milani, 1992, p.77-99).

Tahirih possessed a rare seldom seen in a woman in mid-nineteenth century Iran (Root, 2000). Her attachment to the religious forums and conversations, enthusiastically taught her to defend her ideas. In the foundation of her thoughts, a kind of belief in Sufism is evident. Her understanding of religion was mystical. In her Ghazals, Tahirih's mystical view of social and human aspirations cannot be ignored. Her writings have a disciplined look that can satisfy everyone's spiritual needs and desires (Abedi, 1380, p.15). One of her famous poems is named Point by Point which is renowned as her signature masterpiece (Lee; 2004, p.4-10). For the women's poetry in Iran, she undoubtedly was the first change maker. But after killing her secretly, though her rouge family members destroyed most of her poems, but others were spreading across Iran (Hatcher \& Hemmat, 2008, p.1-2). Amin Banani, a translator of Tahirih's poetry, said sadly there were no systematic efforts made to collect her verse- nor for some fifty years after her death (Amin, 2005, p.9).

But scholars named John S. Hatcher and Amrollah Hemmat, published two volumes in the name of 'The Poetry of Tahirih' in 2002, containing both English translations and the original Arabic-Persian calligraphy. The first volume was named Adam's Wish (2008), and the second one was The Quickening (2011). 


\section{Parvin Etesami (1907-1941): The First Major Female Poet of Twentieth- century Iran}

Parvin Etesami was the pioneer female poet of Iran. She was a poet who found her way to the future. A realist poet, whose words sometimes take on the colour of romanticism; a poet whose lyrical poems are a reflection of her subtle feelings, expressed with a certain enlightenment. Her poems are a kind of descriptive realism with a new, real, and experimental perception that has a special emotional and imaginative burden (Salim, 1377).

Parvin Etesami was born in Tabriz on March 17, 1907. She was the daughter of Yusef Etesami (1874-1938), a reformist translator and literary journalist. She moved to Tehran with her family when she was six years old. Her literary talent was revealed in her childhood. Parvin has been derogatorily referred to as "her father's daughter" (Davaran, 1994, p.74). Yusef persuaded Parvin to participate in the literary gatherings with his scholar friends which familiarized the young Parvin with Persian literature and trained her in classical Persian poetry in particular. Parvin's art is in this skilful and artistic attitude towards classical Iranian literature. Due to her birth and upbringing in a cultural family and in the field of poetry and literature, she became acquainted with the rich and ancient Persian literature from the very beginning. Therefore, critics have shown reflections of Anwari, Sanai and Saadi in her works, but Parvin has been able to write her poem with a simple and psychological language that has the linguistic elements of her time, with a language close to a kind of dialogue and communication. Sharing with today's audience, this is what has enabled her to reach a wide range of audiences, which is not a small thing in the field of art, fortune, and science (Emami, 1390, p. 81).

A poet like Parvin Etesami, who wrote poetry in a not-so-soft language, regardless of gender, played a role in culture and helped to change this attitude between people and society with the position she gained; Of course, even in that period, the greats of literature could not believe that these poems belonged to a woman and that a female poet composed such poems. For this reason, Parvin Etesami was repeatedly beaten and slandered, saying that her poems were not her poems but the poems of Bahar! (Mosharraf, 2012). Although her life span of 35 years is not very colourful in terms of literary composition, but her only book 'Diwane Parvin Etesami' is very rich in the standard of literature. The most influential significance of Parvin's poetry is the priority of social justice over 
political liberty (Ahmadi, 2006, p.44). She revived 'monazereh', the tradition of dialogical strife poetry, in twentieth century Persian literature (Abedi, 1380, p.3042). Parvin has never directly and explicitly criticized on political issues, the description of her poetry is a critique of society which is a lot of political and social issues. There was love, humour, and social thoughts in her poetry (Slezy, 1984). Parvin's poetry has sometimes been criticized for too blindly endorsing patriarchy in her poetry and for choosing "the calm niche of traditional poetry" rather than "fishing for new ideas" (Davaran, 1994, p.74). But poet Parvin Etesami, is one of the few majestic women who have found a place in the literary space of Iran by breaking the cycle of despair and deprivation and nurtured the tenderness of the women's heart in poetry.

\section{Forough Farrokhzad (1935-1967): The Iconoclastic Poet}

After Parvin Etesami's death, many rumours were spread against her, and this is a sign of Iran's anti-woman literary community from ancient times to the postconstitutional period, which continued for many years. However, it was the great poets like Bahar and Dehkhoda who defended; In any case, women's activism in the West has a history of four hundred years, and the expectation that we will see the acceptance of women poets by the literary and general community shortly after the Constitution was a great expectation that did not fit into the infrastructure of the society at that time (Ahmadi, 2004, p.141-152). But Parvin paved the way of women's poetry through which Forough came and poured all her femininity into the poem. She was a taboo-breaker and broke many taboos with her philosophical-socio-political themes and concepts she dealt with in her poetry (Hanaway, 1990, p.57). Forough always put emphasis on the importance of being a human, whatever their gender is.

Forough Farrokhzad was born in Tehran in 1935 as the third of seven children of Colonel Mohammad Bagher Farrokhzad and his wife Touran Vaziri-Tabar. She learned painting and sewing in the school, where she studied up to class 9. She started writing poem (particularly Ghazal) from the age of 13 or 14. Forough Farrokhzad did not have a stable married life. She got married at the age of sixteen and got divorced in 1954. She had a son. But after the birth of her child, she got separated from her husband and her husband, Parviz Shapour, did not allow her to see him until the last day of her life (Dahbozorgi, 1384, p. 97). Her son was brought up with the impression that she has abandoned him for her 
personal pleasure in the name of poetry. This thought caused heart-breaking grief for her (Wolpe, 2007). Farrokhzad died only at the age of 32, but during this short span of her life, she has left a great deal of significant poetical treasure which brought a great change in Iranian women's life forever (Dabashi, 2012).

Forough's position is especially prominent in comparison with other female poets. The themes she raised in poetry and her feminine views of the world and issues are largely unprecedented in women's poetry (Shamissa, 1376, p.16). In the influence of women's poetry on the language of poetry, it should be said that the language of poetry and the beginning of simplification, which came to Iran from the time of translation literature, entered poetry from the time of Forough (Milani, 1992, p. 127-151). In Forough's poems, we have witnessed simplification and softness of language. She turned to simplification with the influence of poetry by women poets around the world, such as Sylvia Plot and Anna Akhmatova (Aidani, 2005). She chose a simple and up-to-date language for her quatrains, which originated from the same effects. Forough was called a villain and since then she had been subjected to many atrocities. "I run away from these people who seem to be my companions and are the same colour, but inwardly, out of humiliation, they tied two hundred shirts around my neck," she said in a radio interview (Milani, 2016). It was the circumstances in which Forough saw the lives of the women around her and her sisters and wrote many poems in her poetry booklets (Hosseini, 2017). However, modernism, with all the strengths and weaknesses of Forough's poetry and thought, entered the body of Iranian poetry with Forough's poetry and its taboos. Sometimes it went beyond feminism and sometimes alongside feminism and paved the way for many poets of that decade and subsequent decades (Mir Hosseini, 2004). Men and women poets whose poetic world were changing even two or three decades later by reading the last book of poetry published by Forough. In any case, this shows Forough's courage and boldness (Rahimi, 1388). According to Nader Naderpour, as an exemplary modernist woman poet, Forough widened the closed window of female literature for women poets of post revolutionary Iran (Zarei, 2017). Shole Wolpe said that Farrokhzad was the poet of protest who helped Iranian women to realize and rediscover their innermost world (Wolpe, 2012).

\section{Simin Behbahani ( 1927-2014):The Lioness of Iran}

Simin Behbahani, famous for her Ghazal-style poems, is an eloquent poet who set the course of classical Iranian literature to a new-classic lyrical way with a 
realistic look (Abedi, 1380, p.53). She got the Noble Prize nomination twice, and winner of enormous literary rewards and international appreciation (Ahmadi, 2006). As a fearless persona of modern Persian poetry of Iran, she got the title of the lioness of Iran (Keshavarz, 2007, p.136).

She was daughter of literary parents. Abbas Khalili, who himself was a writer and newspaper editor was her father. Her mother Fakhr Ozma Arghoon was also a noted feminist and poet. Prior to her birth, her father was temporarily exiled as for violating government rules. After her parents got separated Simin stayed with her mother who encouraged her to write. At the age of twelve she started writing poems and got her first publication when she was only 14 . When she got married to Hassan Behbahani, she took her husband's surname. Behbahani completed her law degree at the University of Tehran after her divorce from her first husband. She re-married in 1969, But she did not change her surname. In the beginning she used to write in modern free verse style, later she switched to writing Ghazals on the daily life of normal Iranian people. With this new style, she added the iconic non-literal subjects like daily life conversations and incidents which marked a historical addition to Iranian literature (Martin, 2014).

Behbahani is a poet who seeks and has carefully and curiously conveyed her poetic moments in literary continuity and has slowly moved from the classical (neo-youth), neo-classical (youth) mentality to neo-modernism (middle age) (Abedi, 1380, p.53). Undoubtedly, one cannot fail to mention the power of attraction of the poet's mind. As in the face of the knowledge and literary works of the past and present of Iran, and the culture and literature of the West, the earth has reached a literary position with a special awareness and perception: thoughtful and not in a hurry. With the blend of these two perceptions, Behbahani created a unique style of her own. In her poems, she has relied on the direct narrative aspect; issues such as poverty, prostitution, theft, in general, social disorder in classes are depicted and described in front of the reader's eyes. (Abedi, 2017, p.380). Because of her extrovert voice towards human rights, she had to constantly face events like arrests and threats of censorship. She was even beaten by Police several times and used to be interrogated unnecessarily before her international flights (Lahiji, 2009).

The atmosphere of Simin's poem apparently shows a traditional society. But this traditional society with all its symbols can be conform to the global modern community, because symbolistic poems pass spatio-temporal borders and enter 
the scene of global community from all periods. (Ebrahimi \& Ebrahimi, 2017). About the style of Simin, in his book named 'Perspectives on Contemporary Iranian Poetry', Dr. Sayed Mahadi Zarghani said, 'Simin's name always reminds me of Parvin and Forough. It is not that the femininity of all three poets is the reason for this association, but rather the quality of their interaction with the cultural tradition of their time that puts their names together. Parvin is a poet who stands in the heart of tradition and her poems are often reminiscent of the beliefs of traditional Iranian women. Forough is exactly her opposite. That is, unlike Parvin, she has risen up against tradition and culture. She takes an axe and ruthlessly - sometimes with her eyes closed - inflicts devastating blows on the concrete walls of the cultural tradition and does not consent to anything less than the destruction of her own house. Simin is right between the two. That is, she crawls out of the heart of the patriarchal cultural tradition and slowly, calmly, and patiently fights with this tradition. She does not have Forough's acceleration, nor does she want to drive everything out so rebelliously' (Zarghani, 1383, p. 381382).

Simin Behbahani was a strong proof of the real position of women's poetry and a fierce defence of all women poets who in classical poetry, due to the conditions of society, did not even get their letters to literary memoirs (Jafi, 2006). She addressed the issues of the day in the form of sonnets in the language of the day (Behbahani, 2007). She used image and space in her sonnets as her famous poems have been remembered among the people and have remained in the minds of the people and her audience. Her poems are undoubtedly the best specimen of modern Persian literature.

\section{Granaz Mousavi (1976-present): A Voice in Exile}

Fereshteh Sari, Shiva Aristavi, Mehrnoosh Ghorbanali, Roza Jamali are some of the notable names among the influential poets of the seventies who, of course, have been writing since the sixties and have matured in the seventies. But the most known poet of this generation is Granaz Mousavi.

Granaz Mousavi (born in 1976) is an Iranian-Australian contemporary poet, film director and screenwriter. She is famously known for her Avant-Garde poetry. Her Australian-Iranian award-winning debut feature film My Tehran for Sale has brought her to the international media limelight. She represents the female poets of Iranian diasporas literature. She is from the latest generations of Iranian poets 
after the revolution, often mentioned as 'scorched generations'. In her childhood, she has witnessed the Iran-Iraq war which erupted her peaceful upbringing. In 1997 Granaz emigrated to Australia with her parents (Vakil, 2011).

In 1996, Granaz published her first book from underground in Tehran, but the book got an extensive reception. But she actually shone with her second collection Pa berahneh Ta Sobh (Barefoot until morning), published in 2000. This book won the "Karnameh Award" in the year in 2001. The poems of this collection became the model and reference of many poets after her and still go hand in hand and word of mouth. Granaz has that spark of strong polemics and fearless voice that we can see in modern day women poetry. Granaz has developed her own unique and original voice in her poetry. She has focused on the 'sexual indifference' mostly that she feels are damaging the social order from within (Soroudi, 1979, p.3-41). Granaz intended to evaluate Iranian women's uniformity and selfless. She challenges the classic way to look to a woman through her poetical and visual works. She raised her voice against the hypocrisy of the society to favour a masculine culture rather than the true feminine nature (Fazaeli, 2016).

\section{The Effect of Gender on the Language of Contemporary Women Poets}

As the above discussion indicates, the path of Iranian women writers had never been smooth. They had to pave their way through a thousand adversities. To fight with all those barriers to break all the social taboos, the pioneer ladies put their emphasis on their literal language, and they have proven that their gender is not an obstacle on blooming their literary talents. Be it with their family or with the society, they always came out strong with their striking lingual abilities. They have shown that language is one of the behaviours through which each person reveals the sexual identity; but it can never be said that a language is purely feminine or masculine (Abedi, 1380, p.17). Most scholars in social linguistics and sociology of language and feminist critics believe that there are differences between male and female languages (Mir Hosseini, 1999), some thinks these differences are due to physiological differences between men and women while another group have considered it the source of men's influence on the language, which has led to the emergence of the kind of masculine language. But the persistent women poets of Iran have proven that language is merely the carrier of the thoughts and emotions of human beings, and as the thoughts and emotions of 
men and women are intertwined, it affects their language in a different way (Dehkhoda, 2011). And the degree of orthodoxy is prevalent among women poets whose poetry has been studied.

Along with the globalization of feminism, issues of women's concern have been the focus of attention in Iranian women's writing as well as with the constitutional revolution and various institutions and bodies. Because of the Iranian women's movement, which majorly influenced the female poets, the situation of women in Iran began to transform (Vahida, 1376). According to Sanasarian, the women's movement was made up of middle and upper-class women whose focus was primarily on the need to voice their needs, both inside and outside the society (Sanasarian, 2007, p.842). These developments have greatly influenced Iranian women's thought and have become the agents of the poets and writers who came to shine through her feminine identity. Undoubtedly, they had to face a lot of troubles, they had to fight really hard. But through their persistent effort and magical writings, the path finder female poets of Iran finally overcame with all the hardships and set the trends in their favour. They proved their gender has no place on the way to make their points. This trend continued after the victory of the Islamic Revolution and led to the emergence of female poets reflecting on women's problems. Poets like Shideh Taami, Khatre Hejazi, Fereshteh Sari, Nazanin Nezami Shahidi, Nahid Kabiri, Shiva Arastuu'ii, Roya Taftii, Pegah Ahmadi, Roza Jamali, Farakhandeh Hajizadeh, Hila Sadighi are the trendsetters of this kind of writing. Thus, contemporary women poets, in addition to starting to compose poetry in the new political-social space, also paid attention to her feminine identity (Moghissi, 1994), which was instrumental in the formation of the so-called feminine language in their poetry.

\section{Conclusion}

Literature is the reflection of its composers heartfelt feelings. On that note, it is very unethical to categorize any form of literature by gender aspects. Unfortunately, like the literary history of the world, women contributions were almost absent in Persian literature for a long time. Their participation in literature was under restriction by the very socio-political and religious inequality. But that does not stop them to discover themselves and portray their feelings in front of the world. They never give up in the face of adversity. Whether they live or die, whether they live in Iran or not, the persistent female poets of Iran, despite their 
own different situations, writing styles and mental strength, have always fight for establishing their individual identity. They always marked their works as the process of finding their 'Self' in the real world. Therefore, it would not be an exaggeration to say that in case of women empowerment in poetical sector, after crossing a long, painful, and difficult way, finally, Modern Persian literature is undoubtedly by the women, and for the women.

\section{References}

Abedi, K. (1380). Be Ragme Panjerehaye Baste: Sher-e Mo'aser Zanan [Despite the Closed Windows: Contemporary Women's Poetry]. Tehran: Nashre Kitabe Nader.

Abedi, K. (2017). Moghaddamei bar She'r e Farsi dar Sade e Bistom e Miladi [ An Introduction to Persian poetry in Twentieth Century]. Tehran: Jahan-e Ketab Publication.

Ahmadi, P. (2006). Women's Poetry from Beginning to Today. Tehran: Cheshmeh Publication.

Ahmadi, W. (2004). The Institution of Persian Literature and The Genealogy of Bahar's "Stylistics". British Journal of Middle Eastern Studies, 31(2), 5-6. Retrieved from https://www.researchgate.net/publication/262946740

The_institution_of_Persian_literature_and_the_genealogy_of_Bahar's_stylistics (Accessed on January 2, 2021).

Aidani, M. (2005). The Authenticity of Forough Farrokhzad: Her Poetry, Desire and Poetics of Body and Self. Retrieved from www.forughfarrokhzad.org/papers/aidani.pdf (Accessed on September 25, 2020).

Amin, B. (2005). Tahirih A Portrait in Poetry. LA, USA: Kalimat Press.

Behbahani, S. (2007). Collection of Poetries. Tehran: Negah Publication.

Brown, E. G. (1969). A Literary History of Persia (Vol-2). Kolkata: Cambridge University Press.

Chopra, R. M. (2010). Eminent Poetesses of Persian. Kolkata: Iran Society.

Dabashi, H. (2012). The World of Persian Literary Humanism. USA: Harvard University Press.

Dahbozorgi, G. H. (1384). Adabiyate Moa'sere Iran Ba Guzideyi Az Sher O Dastan-e Moa'ser [Contemporary Literature of Iran with Selective Contemporary Poems and Stories]. Tehran: Zawvar Press.

Davaran, F. (1994). Impersonality in Parvin E’tesami's Poetry. In H. Moayyad, (Ed.), Once a Dew Drop: Essays on the Poetry of Parvin E'tesami (pp. 69-89). Costa Mesa, California: Mazda Publishers.

Dehkhoda, A. (2011). Amsal Va Hikam [Proverbs and Sentences]. Tehran: Parmis.

Ebrahimi, M., \& Ebrahimi, M. (2017). Women Issues from the Point of View of Simin Behbahani, an Iranian Poet. Journal of History Culture and Art Research, 6(3), 138-152. doi: 10.7596/taksad.v6i3.667

Effendi, S. (1944). God Passes By. Wilmette, Illinois, USA: Baha-i Publishing Trust.

Emami, S. (1390). Sher-e Moa'sere Iran (Ta Enqelab-e Islami) [Iranian Contemporary Poetry [Up to Islamic Revolution]. Tehran: Organization for the Study and Compilation of University Humanities Books.

Fazaeli, R. (2016). Islamic Feminisms: Rights and Interpretations Across Generations in Iran. UK: Taylor \& Francis. 
Hamideh, S. (2007). Women and Politics in Iran: Veiling, Unveiling and Revealing. New York: Cambridge University Press.

Hanaway, W. L. (1990). Bazghashte Adabi [Literary Return]. Ed. Ehsan Yarshater. Encyclopedia Iranica. London: Routledge and Kegan Paul.

Hatcher, J. S., \& Hemmat, A. (2008). Adam's Wish- Unknown Poetry of Tahirih. Wilmette, Illinois, USA: Baha-i Publishing Trust.

Hosseini, M. (2017). Iranian Women's Poetry from the Constitutional Revolution to the PostRevolution (Ph.D. Thesis, University of Sussex, United Kingdom). Retrieved from http://sro.sussex.ac.uk/id/eprint/72558/1/Hosseini\%2C\%20Mahrokhsadat.pdf

Jafi, A. H. (2006). Contemporary Persian Poetical Trends. Tehran: Amir Kabir Publications.

Keshavarz, F. (2007, July 13). Banishing the Ghosts of Iran. The Chronicle of Higher Education. Retrieved from https://www.chronicle.com/article/banishing-the-ghosts-of-iran/ (Accessed on December 21, 2020)

Kianush, M. (1996). Modern Persian Poetry. New York: Rockingham Printing Press.

Lahiji, S. (2009). Recognition of the Identity of Iranian Women. Tehran: Enlightenment and Women Studies.

Lee, A. (2004). Tahirih A Portrait in Poetry: Selected Poems of Qurratul 'Ayn. LA, USA: Kalimat Press.

Ma'ani, B. R. (2008). Leaves of the Twin Divine Trees. Oxford, UK: George Ronald.

Maneck, Susan. (1994). Religion and Women. Albany: Sunny Press.

Martin, D. (2014, August 21). Simin Behbahani, Outspoken Iranian Poet, dies at 87. The New York Times. Retrieved from https://www.nytimes.com/2014/08/22/arts/international/siminbehbahani-outspoken-iranian-poet-dies-at-87.html (Accessed on October 21, 2020).

Milani, F. (1992). Veils and Words: The Emerging Voices of Iranian Women Writers. New York: Syracuse University Press.

Milani, F. (2016). Forough Farrokhzad: A Literary Biography with Unpublished Letters. Canada: Persian Circle.

Mirabedini, H. (2005). The History of the Female Story Writer. Retrieved from http://www.iranchamber.com/literature/articles/history_female_storywriters.php (Accessed on November 2, 2020)

Mir Hosseini, Z. (1999). Islam and Gender: The Religious debate in Contemporary Iran. Princeton: Princeton University Press.

Mir Hosseini, Z. (2004). The Quest for Gender Justice Emerging Feminist Voices in Islam. Journal of Islam, 21 (36), 1-5.

Moghaddam, R. (2019). Struggle for Equality from the Constitutional Revolution to Cyber feminism with a Focus on the Role of New Media in the Women's Movement in Iran (Doctoral Thesis, Freie Universität Berlin, Germany). Retrieved from https://refubium.fuberlin.de/bitstream/handle/fub188/26347/Dissertation_Rezvan.pdf?sequence=4\&isAllowed=y

Moghissi, H. (1994). Populism and Feminism in Iran: Women's struggle in a Male-Defined Revolutionary Movement. New York: St. Martin's Press Inc.

Mosharraf, M. (2012). Parvin E'tesami: Payegozare Adabiyat-e Neokelasik-e Iran. Tehran: Sokhan. 
Rahimi, Z. (1388). Man of The Millennium: A Comparative Study of Male and Female Behavior in Forough's and Saffarzadeh's Poem. Isfahan: Payam Alavi.

Root, M. L. (2000). Tahirih The Pure. LA, USA: Kalimat Press.

Rypka, J. (1968). History of Iranian Literature. Holland: Reidel Publishing Company.

Salim, G. R. (1377). Sociology or Social Literature in Persian Literature. Tehran: Toos.

Sattari, J. (2009). The Portrait of a Woman in Iranian Culture. Tehran: Markaz.

Shafi'i Kadkani, M. R. (2013). Ba Cheragh va Ayeneh [With Light and Mirror]. Tehran: Sokhan.

Shamissa, C. (1376). Negahi Be Forough [Forough Farrokhzad (a commentary on poems)]. Tehran: Morvarid Publication.

Slezy, P. (1984). Parvin E'tesami: A Biography and 60 Poems in Russian Translation. Retrieved from https://iranicaonline.org/articles/etesami-parvin (Accessed on January 2, 2021).

Smith, P. (2000). Tahirih A Concise Encyclopedia of the Baha-i Faith. Oxford: One World Publications.

Sanasarian, E. (2007). Global Feminism: Transnational Women's Activism, Organizing and Human Rights. UK: Cambridge University Press.

Soroudi, S. (1979). Poet and Revolution: The Impact of Iran's Constitutional Revolution on the Social and Literary Outlook of the Poets of the Time: Part 1. Iranian Studies, 12(1/2), 3-41. Retrieved from https://www.jstor.org/stable/4310308?seq=1 (Accessed on November 23, 2020).

Vahida, F. (1376). Step in the Field of Sociology of Literature, Iranian Sociology Association Letter. Article's Collection. Retrieved from https://www.researchgate.net/publication/ 279742312_Social_Ideas_in_Poetry_of_Four_Female_Contemporary_Poet_Parvin_Etesami_ Forough_Farokhzad_Tahereh_Safarzadeh_and_Simin_Behbahani (Accessed on December 13, 2020).

Vakil, S. (2011). Women and Politics in the Islamic Republic of Iran: Action and Reaction. Sydney: Bloomsbury.

Wolpe, S. (2007). Sin: Selected Poems of Forough Farrokhzad. Canada: University of Arkansas Press.

Wolpe, S. (2012). The Forbidden: Poems from Iran and It's Exiles. USA: Michigan State University Press.

Zarei, R. (2017). The Beloved in Nader Naderpour's Poetry. Transnational Literature, 10(1). Retrieved from https://dspace.flinders.edu.au/xmlui/bitstream/handle/2328/37634/ Zarei_The Beloved_in_Nader_Naderpour.pdf?sequence=1 (Accessed on November 3, 2020).

Zarghani, S.M. (1383). Cheshm Andoz Sher-e Moa'ser-e Iran [Perspectives on Contemporary Iranian Poetry]. Tehran: Saless Publication. 
